\title{
Food Security of Banjar People In Facing Climate Change In Sungai Batang Village, Banjar District, South Kalimantan
}

\author{
Setia Budhi ${ }^{1}$, Sri Hidayah ${ }^{1}$, Ismar Hamid ${ }^{1}$, Siti Aulia ${ }^{1,}$ Muhammad Agrianto Suwandi ${ }^{1}$ \\ ${ }^{1}$ Department of Sociology, Universitas Lambung Mangkurat, Indonesia.
}

Article Info

Accepted: 31 March 2021
Published: 9 April 2021

\section{Keywords: \\ Food Security \\ Banjar People \\ Climate Change}

\begin{abstract}
In the last five years, the world's attention has shifted to food security in relation to climate change adaptation and mitigation, particularly in 2008, when food prices skyrocketed, causing famine in Cape Africa and even the Sahel, which is still feeling the effects of this famine in 2012. In the same year, the OHCHR report (the Office of the United Nations High Commissioner for Human Rights) notes the need to safeguard food security and nutrition in the context of Human Rights. A major shift occurred in Indonesian agriculture due to the 1999 eruption of Mount Elanor. A focus on climate influences has been a prominent component of the Indonesian government's policy regarding agriculture for some time. Plant-resistant crops or programs for mitigating climate change take the form of either of these options. Culminating a significant development in policies to secure food security, such as protection of agricultural land, various policies were created to evaluate land use and regulations of the Minister of Agriculture pertaining to guidelines for land use. The study, which was done for a period of six months, has a goal of learning more about the Banjar people's local knowledge on climate change. By collecting data from locals, such as farmers, community leaders, and village heads, who have detailed knowledge about Banjar customs and traditions, and from Banjar people who are selected for the research in Banjar Regency, South Kalimantan, qualitative methods and collection of local knowledge and local wisdom strategies were employed.
\end{abstract}

\section{Copyright and License:}

Authors retain copyright and grant the journal right of first publication with the work simultaneously licensed under a Creative Commons Attribution 4.0 International License that allows others to share the work with an acknowledgment of the work's authorship and initial publication in this journal.

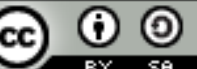

\section{INTRODUCTION}

Climate change has an adverse effect on many aspects of life, including the food crisis. Food scarcity has emerged as a disruptive effect, with the potential to cause famine in many parts of the world, including Indonesia. Food security is achievable if it synergizes with and goes hand in hand 
with climate resilience. Food, energy, and water security programs must be prioritized as basic human needs in this new normal era.

According to Yunita Triwardini Winarto's (2020) analysis, in a situation of climate change with increasingly uncertain consequences and increasing climate diversity, farmers' responsiveness in dealing with these conditions is required so that agriculture can be sustained in a resilient (sustainable) manner. Adaptive agricultural activity to the effects of climate change can only be achieved if farmers are able to anticipate and respond to crop failure risks.

Research on sustainable education programs like " Climate Village," "The Science Field Shops," and others is an important example of how pilots can be considered for dissemination. Climate services in a dialogic-participatory-interactive learning arena with farmers as researchers, anticipators, and decision makers armed with more detailed and in-depth knowledge of the impact of certain rainfall conditions on land and crops, future climate scenario services for the next three months, and similar experiences in the past.

When dealing with local disasters and global issues such as COVID-19 and Climate Change, adaptive food security is critical to ensuring that people's food needs are met. Faced with the problem of COVID-19, climate change, and local disasters, adaptive food security can use existing concepts at the community level with their traditional knowledge, work together to help each other and collaborate, as well as share experiences and technology in meeting primary needs in the form of food.

The goal of this study was to gain an understanding of the food security conditions and food security planning implemented for the Banjar people in Sungai Batang village in order to ensure the sustainability of their way of life. In the face of climate change, the research specification was developed to examine the consumption diversification technique in relation to the availability of local food sources in Sungai Batang village.

\section{METHODOLOGY}

This study's scope includes identifying Banjar Farmers in relation to food security and climate change in the area of village profiles, basic needs, and programs that have been developed. This research is also linked to the identification of several problems in the socioecological development of Banjar farmers, the hopes and existence of the community that are embedded in it are inhibiting and potential factors that can be developed.

This study takes an ethnographic approach to understanding and analyzing the problems faced by the Banjar farmer community, how they face the global era, and how the formulation is obtained from the development and empowerment strategy model against the effects of climate change.

This study is being conducted in the context of Indigenous Knowledge. The purpose of the qualitative description of Indigenous Knowledge is to see how local wisdom and local knowledge of the community in the research area can be used to provide an understanding of the development of community empowerment. Indigenous science developed independently of Western science. "If we define 'indigenous' as people who have a long-standing and complex relationship with their local environment, and'science' as a systematic approach to acquiring knowledge of the natural world, then Indigenous science is the process by which Indigenous people build their empirical knowledge of their natural environment. Indigenous science, like Western science, is the practical application of theories of knowledge about the nature of the world, and Indigenous people are increasingly incorporating Western scientific knowledge into their practices "..

Field observations were already taking place when the research team entered the sub-district area to explain the social setting of community life in the research location. The attention of the 
research team cannot be separated from the observation and situation of flood disasters, such as land access, housing conditions, religious facilities, government buildings, the existence of schools, and community activities. At the research site, in-depth interviews were conducted with members of the farming community, heads of farmer groups, and, in particular, Banjar farmers. This interview will look into the impact of food security on climate change, as well as farmers' responses to climate change. Focus Group Discussion (FGD) also entails interviewing researchers with a large group of people. As informants, BPD members, community empowerment activists, village heads, and several village farmers engaged in question-and-answer sessions or focused discussions.

Sungai Batang Village, Martapura Timur District, Banjar Regency is the primary research site. Preliminary observations show that from the 7th to the 10th of February 2021, this village was flooded, and nearly all of the people's agricultural land was flooded. This flood disaster site is the most appropriate choice for the research location because Sungai Batang Village, which has a population of $90 \%$ Banjarese, is the most appropriate choice.

\section{FINDINGS AND DISCUSSION}

Climate change is a dynamic and continuous process whose impact has been felt heavily, particularly in the agricultural sector, either directly or indirectly. Agriculture, particularly the food crop sub-sector, is particularly vulnerable to climate change due to three major factors: biophysics, genetics, and management (Las and Surmaini, 2011). Climate change has reduced food production, particularly in developing countries such as Indonesia. Food production is declining primarily as a result of rising soil temperature and salinity, extreme weather that causes drought and flooding, pest and disease attacks, and reduced production capacity due to damage to agricultural infrastructure. According to studies conducted in the tropics, maize and rice production will decline due to rising temperatures and climate change. A temperature increase of 2 degrees Celsius reduces maize production by $20 \%$ and rice production by $10 \%$. (IPCC, 2007).

According to the Food and Agriculture Organization (FAO), 65 developing countries are at high risk of losing 280 million tonnes of cereal production due to global climate change (Boer, 2010). Southeast Asian countries will suffer more severe losses as a result of climate change, with an average cost of climate change equal to 6.7 percent of GDP annually, particularly in the Philippines, Indonesia, Thailand, and Vietnam, if the usual handling scenario is followed. Rice yields in the Philippines, Indonesia, Vietnam, and Thailand are expected to fall by about 50\% in 2100 compared to the 1990 average, assuming no improvements in technical facilities. Production will fall by $34 \%$ in Indonesia and $75 \%$ in the Philippines, beginning in 2020, and will occur in almost all countries (ADB, 2009).

Elizabeth's research on strategies for achieving food diversification and self-sufficiency suggests a shift in the food pattern of the non-rice community into rice, as has occurred in Madura, Maluku, NTT, Ambon, and other Eastern Indonesia regions. Even Maluku, which used to eat sago as a staple food, has switched to rice (90-100 percent), matching North and West Sumatra (Elizabeth, 2011).

Meanwhile, Hardono's research on local food diversification development strategies revealed that a phenomenon that occurs in several locations such as Nusa Tenggara, Papua, Maluku, and Sulawesi is a shift in people's food patterns away from dominant local foods such as maize, tubers, and sago and toward a shifting pattern. national food (rice), then switched to a wheat-based international diet (Hardono, 2014). 
Understanding the consumption pattern of the Waimangit village community demonstrates that the community's local food consumption is built with various natural conditions as well as local wisdom. Consumption patterns that can be used but have not been fully implemented as a result of changes in the flow of communication and the opening of transportation to various regions in the geographic community, so that they have an influence on patterns of thought and consumption, and community actions are the result of correlation and interaction (Berg, Hebinck, \& Roep, 2018) with people from other communities.

Food insecurity results in a person's limited economic access to food. One indicator of failure to achieve food security is a lack of economic access to food.

Food security is defined in Law No.18 of 2012 concerning Food as a condition for the fulfillment of food for the state to individuals, which is reflected in the availability of sufficient food, both in quantity and quality, safe, diverse, nutritious, equitable, and affordable, and does not conflict with religion, beliefs, and community culture, to be able to live healthy, active, and pr Food security, according to FAO (1996), Barret (2010), Suryana (2014), and Moeke et al. (2015), is the relationship between three elements: (a) food availability and stability; (b) food accessibility, both physically and economically; and (c) food utilization, which means that the food consumed must be sufficient, safe, and nutritious to meet the energy needs for an active life, healthy, and productive. Following the global food crisis of 1972-1974, food security became an international issue (Maxwell and Frankenberger 1992).

Initially, the concept of food security was more concerned with food availability, particularly grains. In line with the growing population and the food crisis, adequate regional food availability does not guarantee adequate access to food consumption at the household level.

Food security will be realized when all people have physical and economic access to safe and nutritious food to meet their needs for an active and healthy life at all times (Saliem et al. 2005). Suryana (2014) also explains that the challenges to achieving food security can be divided into two categories: those arising from the supply side or provision of food supply and those arising from the demand or consumption side of food. Purchasing power will have a significant impact on food demand and consumption. Meanwhile, a household's purchasing power is largely determined by its level of income. As a result, poverty has a significant impact on the quality of a household's food utilization (Zakiah 2016). One of the benchmarks for measuring a person's food security is the quality of food consumption or utilization. This is consistent with the World Conference on Human Rights 1993 and the World Food Summit 1996 concepts of food security (Saliem et al. 2005).

Each region has its own local wisdom, which becomes the identity of an area that can distinguish one region from another. Local wisdom, according to Juhadi (2018), is defined as wise and valuable local ideas that are embedded and followed by community members. Local wisdom is a way of looking at life and knowledge, as well as various life strategies that manifest themselves in activities carried out by local communities in response to various elements of religious life, science, economy, technology, social language organizations, and technology (Suparmini, Setyawati, \& Sumunar, 2014).

Local wisdom is one of the efforts that can be made to reduce the impact of disasters, because it is born from the human ability to understand the environment for survival (Permana, Setyowati, Slamet, \& Juhadi, 2017). Local wisdom is a type of wisdom that exists in a community group and is used as a life guide in carrying out better daily activities (Hardiyanti, Arisal, \& Marhani, 2018). Local wisdom is a very valuable asset that must be preserved, especially given the trend of decreasing public awareness of environmental issues (Anam et al., 2018). Sungai Batang is the village in the Banjar Regency environment studied in this study. This village is a peat village that serves an 
important function in South Kalimantan by protecting lowland areas. Almost 30 percent of the peat ecology in this area has changed in the last ten years as a result of the introduction of large plantations. Changes in agricultural landscapes have an impact. Increased extreme weather and rising sea levels, on the other hand, have resulted in greater abrasion and the degradation of Galam forests and housing development areas as a result of climate change.

According to the Banjar people, food is anything that can be eaten and is filling. According to that definition, Banjar food can be divided into three categories: daily food or staple food, ceremonial food, and snack food or snacks. Rice and side dishes are the most common foods. When comparing the two types of food, the amount of rice is always greater than the amount of side dishes. At each meal, the variety of side dishes is generally limited to one type of river fish cooked in a variety of dishes, accompanied by green vegetables (Gangan) seasoned with chili sauce and salt as stimulants.In the food concept of the Banjar people, the only food that can be filling and fattening is rice. For them, rice is the main food, while side dishes and vegetables only function as additional flavorings. Because of that, the diversity of the menu has never occurred to them. "What is important is wan Iwak rice, and grated kanyang. That is not eaten in this village, even if there are vegetables, such as additional food, mila shoots of gukmbuli, waluh, peanuts or sambai basarai. "The

Estimated area of damaged land in Banjar Regency in 2019-2021. This data illustrates that the potential for peatland damage is quite strong in Banjar District. This shows the potential for food to be threatened. Palawija and other food crops rely on peatlands. However, it is important if the food potential is linked to the farming culture of the Banjar people in the research area.

\begin{tabular}{|c|c|c|c|c|c|}
\hline Subdistrict & $\begin{array}{l}\text { Plant } \\
\text { (Ha) }\end{array}$ & $\begin{array}{c}\text { Damaged } \\
\text { (Ha) }\end{array}$ & $\begin{array}{c}\text { Harvest } \\
\text { (Ha) }\end{array}$ & $\begin{array}{l}\text { Production } \\
\text { (Ton) }\end{array}$ & $\begin{array}{c}\text { Average } \\
\text { Production (Kw / } \\
\text { Ha) }\end{array}$ \\
\hline 01. Aluh-Aluh & 7354 & 331 & 7023 & 28345 & 4,036 \\
\hline $\begin{array}{ll}\text { 02. Beruntung } & \text { Baru }\end{array}$ & 6352 & 451 & 5901 & 21474 & 3,639 \\
\hline 03. Peat & 9171 & 1037 & 8134 & 34495 & 4,241 \\
\hline 04. $\begin{array}{l}\text { Kertak } \\
\text { Hanyar }\end{array}$ & 3260 & 435 & 2825 & 11119 & 39,36 \\
\hline 05. $\begin{array}{l}\text { Tatah } \\
\text { Makmur }\end{array}$ & 2603 & 283 & 2320 & 9006 & 3882 \\
\hline 06. $\begin{array}{l}\text { Sungai } \\
\text { Tabuk }\end{array}$ & 8756 & 621 & 8135 & 30726 & 3,777 \\
\hline 07. Martapura & 1078 & - & 1040 & 3763 & 3,618 \\
\hline $\begin{array}{ll}\text { 08. Martapura } \\
\text { Timur }\end{array}$ & 1505 & 69 & 1436 & 6108 & 4,253 \\
\hline 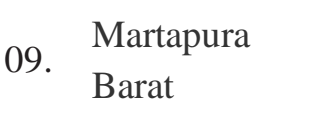 & 6078 & 225 & 5853 & 25088 & 4,286 \\
\hline 10. Astambul & 5045 & - & 4867 & 19809 & 4,070 \\
\hline 11. Karang Intan & 2678 & - & 2584 & 10770 & 4,168 \\
\hline 12. Aranio & 5 & - & 5 & 19 & 3,800 \\
\hline
\end{tabular}




\begin{tabular}{|c|c|c|c|c|c|c|}
\hline 13. & $\begin{array}{l}\text { Sungai } \\
\text { Pinang }\end{array}$ & 160 & - & 154 & 483 & 3,138 \\
\hline 14. & Paramasan & 15 & - & 15 & 47 & 3,100 \\
\hline 15. & Pengaron & 939 & 89 & 850 & 2995 & 3,524 \\
\hline 16. & $\begin{array}{l}\text { Connect } \\
\text { Makmur }\end{array}$ & 683 & - & 659 & 2400 & 3,642 \\
\hline 17. & Mataraman & 2404 & - & 2319 & 8477 & 3,655 \\
\hline 18. & $\begin{array}{l}\text { Simpang } \\
\text { Empat }\end{array}$ & 6042 & 326 & 5716 & 20509 & 3,588 \\
\hline 19. & $\begin{array}{l}\text { Telaga } \\
\text { Bauntung }\end{array}$ & 305 & 8 & 286 & 982 & 3,434 \\
\hline & Total & 64433 & 3875 & 60122 & 236614 & 3,936 \\
\hline
\end{tabular}

Data source: BPS Banjar Regency 2021

Food security in Banjar people varies due to the diversity of food resources, local institutions, and culture that encourage the development of agricultural businesses. Nonetheless, farmers' access to agricultural financing sources is severely limited, in addition to the absence of financial institutions that specifically finance the agricultural sector. The use and availability of agricultural tools and machinery (Alsintan) is still lacking. The existence of labor competition between the agricultural sector and other sectors (industry, services, and trade) resulted in labor scarcity. Alsintan's demand increased as a result of this situation.

In line with the problem of food security in Sungai Batang Village, research shows that the institutional function of agribusiness (government and private enterprises) is still weak to support access to production centers and production pockets. The lack of a culture of storing crops (there are food barns) has resulted in large fluctuations in the price of agricultural commodities during harvest and during famine. Encourage the establishment of rural financial institutions that are culturally appropriate, as well as the establishment of agricultural financial institutions to provide flexible capital for food security and agribusiness development.

On the other hand, developing agricultural tools and machinery and mobilizing community participation in the development of agricultural tools and machinery with the community's social culture is insufficient. As a result, there is no visible independent production facility / kiosk service system at the farm level, aside from encouraging the availability and use of organic fertilizers and non-chemical pesticides (vegetable and biological). Improve coordination and optimize agribusiness institutional functions (agribusiness terminals and sub-terminals) in production centers. Program management with zoning patterns for superior commodities by fostering centers / production centers (KSP). The potential area as a Production Area (KSP) for food crop agriculture and horticulture in Sungai Batang Village by establishing cooperative relationships and partnerships in terms of marketing information, seedlings, training and apprenticeship of officers and farmers.

Table 2 Local knowledge of Banjar Farmers on climate

\begin{tabular}{|l|l|l|l|}
\hline No & Ecosystem and climate change & Adaptation Local Knowledge & Information \\
\hline 01 & Control of water flow & Tabat & Irrigation \\
\hline 02 & Control of soil acidity & Planting Galam Trees & \\
\hline 03 & Control of landslides in & Tihang Carucuk & \\
\hline
\end{tabular}




\begin{tabular}{|l|l|l|l|}
\hline 04 & Pest Control in & Jabak & \\
\hline 05 & Control of Pests & Marabun Data & \\
\hline
\end{tabular}

Source: observation and interviews in May 2021.

According to field research, the 2021 flood had a significant impact on food security for the Banjar people in Sungai Batang Village. The rice that they stored in "kindai" are flooded, and even if the rice can be saved by drying it, it cannot be consumed. During the interview, it was discovered that their cultural adaptation strategy for dealing with floods is to maximize fisheries business, which can be considered an income substitute for the Banjar people.

The research has not found a replacement for the Banjar people of Sunai Batang Village's staple food. As a result, rice is still used as a staple food in the face of climate change. One thing that can be done is to process the Sago tree, which is still found in this village, into Sago flour.

\section{CONCLUSION}

One of the things that is quite concerning is the disruption of the people's food sustainability in the Batang River village due to food security, which is a decrease in the production area. Food security includes not only the issue of guaranteeing a sufficient supply of food for every household, but also a number of additional factors, including the issue of ensuring food is safe, nutritious, varied, and affordable for the public. It's clear, climate change is increasing the likelihood of the extinction of a multitude of species, including the acidification of rivers, the destruction of buffer forests such as the Galam and Nipah forests, and the greatest threat is the decrease in the number of fish that can be caught due to their damaged habitat. With respect to the Banjar people in Sungai Batang Village, Banjar Regency, freshwater fishery business helps to supplement their incomes.

\section{REFERENCES}

Ariningsih E, Rachman HPS. 2008. Strategi peningkatan ketahanan pangan rumah tangga rawan pangan. Anal Kebijak Pertan. 6(3):239-255.

Baldos ULC, Thomas WH. 2014. Global food security in 2050: the role of agriculture productivity and climate change. Aus J Agr Res Econ. (58):554-570.

Barrett CB. 2010. Measuring food insecurity. Science. 327(5967):825-828.

Budhi, Setia (2020) Rethinking Dayak Identity. Komojoyo Press, Yogyakarta.

Chambers R. 2014. Rural development: putting the last first. New York (US): Routledge.

Cook JT, Frank DA. 2008. Food security, poverty, and human development in the United States. Ann N Y Acad Sci. 1136(1):193-209.

Darwanto DH. 2005. Ketahanan pangan berbasis produksi dan kesejahteraan petani. Ilmu Pertanian. 12(2):152-164.

Kementerian Kesehatan RI. 2014. Riset kesehatan dasar 2013. Jakarta (ID): Kementerian Kesehatan RI, Badan Penelitian dan Pengembangan Kesehatan.

Labadarios D, Mchiza ZJR, Steyn NP, Gericke G, Maunder EMW, Davids YD, Parker WA. 2011. Food security in South Africa: a review of national surveys. Bull WHO. 89(12):891-899. 
Moeke PT, Heitia M, Heitia S, Karapu R, Cote S. 2015. Understanding Mäori food security and food sovereignty issues in Whakatäne. MAI J. 4(1):29-42.

Sajogyo. 1977. Golongan miskin dan partisipasi dalam pembangunan desa. Prisma, 6-3-10

Shariff ZM, Khor GL. 2008. Household food insecurity and coping strategies in a poor rural community in Malaysia. Nutr Res Pract. 2(1):26-34.

Spradley, J., (1980). Participant Observation. New York: Holt, Rinehart and Winston.Food and Agriculture Organization of the United Nations. 1996. Rome declaration on world food security. World Food Summit; 1996 Nov 13-17; Rome, Italy. Rome (IT): Food and Agriculture Organization of the United Nations.

Suryana A. 2014. Menuju ketahanan pangan Indonesia berkelanjutan 2025: tantangan dan peluangnya. Forum Penelit Agro Ekononomi. 32(2):123-135.

Todaro, Michael P, Stephen CS. 2000. Pembangunan ekonomi, Jilid 1. Jakarta (ID): Erlangga. 